\title{
Pengaruh Fraksi Coated Fuel Particle pada Desain Pebble Bed Reactor 40 MWt dengan Elemen Bakar Uranium
}

\author{
Dwi Irwanto *1, Nining Yunigsih \\ ${ }^{1}$ Kelompok Keahlian Fisika Nuklir dan Biofisika, Prodi Fisika, Fakultas Matematika dan Ilmu Pengetahuan Alam, Institut Teknologi \\ Bandung, Indonesia
}

\begin{tabular}{l}
\hline INFORMASI ARTIKEL \\
\hline Riwayat Artikel: \\
Diterima: \\
12 November 2020 \\
Diterima dalam bentuk revisi: \\
05 April 2021 \\
Disetujui: \\
24 April 2021 \\
\end{tabular}

Kata kunci: coated fuel particle uranium netronik pebble bed reactor

\begin{abstract}
ABSTRAK
PENGARUH FRAKSI COATED FUEL PARTICLE PADA DESAIN PEBBLE BED REACTOR 40 MWT DENGAN ELEMEN BAKAR URANIUM. Coated Fuel Particle (CFP) adalah tipe elemen bakar mikro berdiameter lebih kecil dari $1 \mathrm{~mm}$, yang di dalamnya terdapat material fisil yang dilapisi oleh beberapa lapisan karbon. Pebble Bed Reactor (PBR) menggunakan konsep CFP untuk elemen bakarnya. CFP dimasukan ke dalam bola elemen bakar berukuran $6 \mathrm{~cm}$ dan disebar di dalam zona elemen bakar. Tujuan penelitian ini adalah untuk mempelajari pengaruh dari fraksi CFP terhadap beberapa parameter neutronik penting seperti faktor multiplikasi efektif, spektrum energi neutron, perubahan densitas material fisil dan fertil, serta tingkat utilisasi material fisil. Analisa dilakukan untuk pada sistem PBR berdaya $40 \mathrm{MWt}$ dengan menggunakan kode Monte Carlo MVP/MVP-BURN, dengan fraksi CFP yang dianalisa berkisar antara $5-60 \%$. Dari penelitian ini didapatkan bahwa fraksi CFP sebesar $10 \%$ memberikan nilai optimal untuk beberapa parameter neutronik terkait dan dapat dijadikan acuan untuk desain Pebble Bed Reactor berdaya $40 \mathrm{MWt}$ dengan elemen bakar uranium.
\end{abstract}

\begin{abstract}
THE EFFECT OF THE COATED FUEL PARTICLE FRACTION FOR 40 MWT URANIUM FUELED PEBBLE BED REACTOR. Coated Fuel Particle (CFP) is a micro fuel with a diameter smaller than $1 \mathrm{~mm}$, in which there is a fissile material covered by several layers of carbon. Pebble Bed Reactor (PBR) uses the CFP concept for its fuel. The CFP is loaded into a $6 \mathrm{~cm}$ fuel ball and spread out in the fuel zone. The purpose of this research was to study the effect of the CFP fraction on several important neutronic parameters, such as the effective multiplication factor, the neutron energy spectrum, changes in the density of fissile and fertile materials, and the utilization rate of the fissile material. The analysis was carried out for a $40 \mathrm{MWt}$ PBR system using the Monte Carlo MVP/MVP-BURN code, with the CFP fraction analyzed ranging from 5$60 \%$. From this research, it was found that the CFP fraction of $10 \%$ gave the optimal value for several related neutronic parameters and could be used as a reference for the design of $40 \mathrm{MWt}$ Pebble Bed Reactor using uranium fuel.

Keywords: coated fuel particle, uranium, netronik, pebble bed reactor
\end{abstract}

\section{PENDAHULUAN}

High Temperature Gas Reactor (HTGR) merupakan salah satu tipe reaktor yang memiliki potensi besar untuk dikembangkan. Selain untuk menghasilkan daya listrik, tipe reaktor ini pun dapat dimanfaatkan untuk keperluan kogenerasi dan insdustri yang memanfaatkan panas yang dihasilkan dari keluaran reaktor ini, seperti proses pemurnian air laut, produksi hidrogen, enhance oil recovery dan berbagai keperluan industri lainnya.

*Penulis korespondensi.

E-mail: dirwanto@fi.itb.ac.id
Terdapat dua tipe HTGR, yaitu tipe prismatik dan tipe pebble bed. Kedua tipe ini menggunakan elemen bakar bertipe Coated Fuel Particle (CFP) yang terdiri dari elemen bakar nuklir (bisa berupa Uranium, Thorium atau Plutonium) yang dilapisi oleh tiga jenis lapisan karbon [1,2]. Salah satu perbedaan antara tipe prismatik dan pebble bed, terdapat pada bagaimana CFP ini dibentuk menjadi elemen bakar dan ditempatkan di dalam teras. Tipe prismatik menempatkan CFP dalam pin elemen bakar berbentuk silinder yang kemudian disimpan dalam batang elemen bakar dan assembly berbentuk segi-enam. 


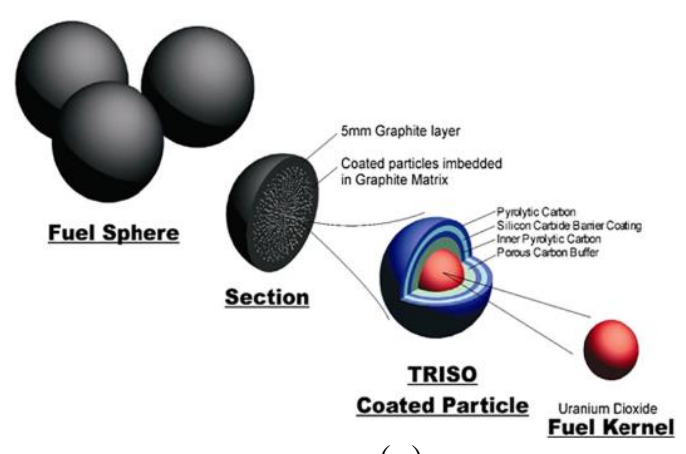

(a)

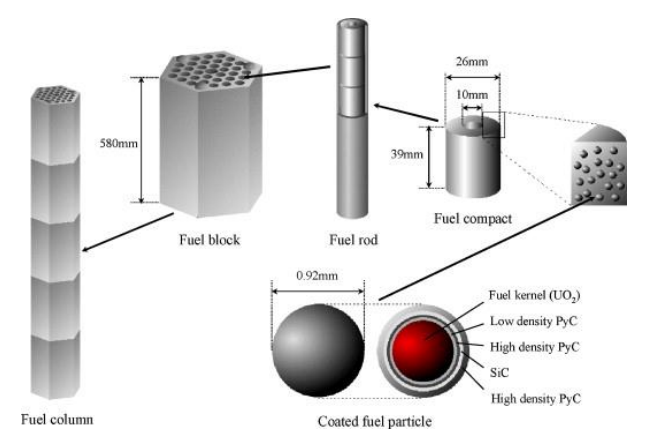

(b)

Gambar 1. Dua tipe konfigurasi CFP pada bahan bakar HTGR; (a) tipe pebble bed [3] (b) tipe prismatik [4].

Sedangkan tipe pebble bed menempatkan CFP dalam bola-bola elemen bakar yang kemudian disimpan di dalam teras reaktor, seperti diilustrasikan pada Gambar 1.

Setiap coated fuel particle mengandung material elemen bakar dan beberapa lapisan karbon, sehingga jumlah CFP di dalam sebuah bola elemen bakar akan mempengaruhi perbandingan jumlah elemen bakar terhadap moderator. Hal ini juga akan mempengaruhi parameter neutronik dari reaktor HTGR tipe pebble bed berdaya 40 MWt dengan elemen bakar uranium, seperti faktor multiplikasi efektif, spektrum energi neutron, densitas material fertil dan fisil serta utilisasi material fisil, yang tentu saja juga akan mempengaruhi aspek hidrolika panas dan keselamatan reaktor.

Setiap desain reaktor akan memiliki nilai optimal yang unik untuk setiap parameternya. Misalnya, HTR-10, memiliki jumlah CFP sekitar 8300 [3], PBMR memilki jumlah CFP sebanyak 15000 [5], dan HTR-PM memiliki jumlah CFP sebanyak 12000 [6], serta akan berbeda pula untuk reaktor HTGR tipe pebble bed berdaya 40 MWt. Jumlah CFP ini ditentukan dengan mempertimbangkan aspek neutronik, hidrolika panas dan keselamatan reaktor tersebut. Sehingga dalam merancang desain sebuah reaktor, kita tidak bisa dengan serta merta menggunakan nilai parameter yang digunakan pada desain reaktor lain, tetapi kita perlu mencari nilai optimal parameter desain reaktor yang kita rancang.

Beberapa penelitian mengenai tinjauan neutronik pada HTGR tipe pebble bed serta penggunaan CFP telah dilakukan [7-9]. Tujuan dari penelitian ini adalah untuk mempelajari pengaruh fraksi CFP terhadap beberapa parameter penting neutronik seperti faktor multiplikasi efektif, spektrum energi neutron, densitas material fertil dan fisil serta utilisasi material fisil pada desain HTGR tipe pebble bed berdaya $40 \mathrm{MWt}$ dengan elemen bakar uranium, kemudian mencari nilai optimal jumlah CFP yang dapat digunakan.

\section{SPESIFIKASI ELEMEN BAKAR DAN DESAIN REAKTOR}

Untuk mempelajari pengaruh fraksi coated fuel particle di dalam bola elemen bakar serta penggunaannya pada desain pebble bed reactor, serangkaian perhitungan dengan menggunakan desain elemen bakar dan spesifikasi reaktor tertentu perlu dilakukan.

\subsection{Spesifikasi Elemen Bakar}

Desain, dimensi, jenis elemen bakar serta pengkayaan serta fraksi CFP yang digunakan pada penelitian ini ditunjukkan pada Tabel 1 dan 2. Pada studi ini, radius kernel serta ketebalan dan densitas setiap lapisan TRISO yang digunakan memiliki nilai yang nyaris sama dengan yang digunakan pada HTR-10, HTR-PM dan PBMR, kecuali untuk ketebalan dan dimensi lapisan pertama PyC yang sedikit berbeda. Sedangkan untuk nilai pengkayaan, digunakan nilai pengkayaan sebesar $10 \%$, yang sangat dekat dengan nilai pengkayaan PBMR sebesar 9,6\%. Hal ini dikarenakan fokus pada penelitian ini adalah mempelajari dan menemukan nilai optimal fraksi CFP pada beberapa parameter neutronik penting, dengan variasi CFP antara 5-60\%. Variasi CFP ini akan menambah total jumlah elemen bakar dan material fisil di dalam bola elemen bakar, sehingga nilai pengkayaan yang 
terlalu tinggi, seperti yang digunakan pada HTR-10 dan HTR-PM akan mengurangi sensitifitas efek perubahan fraksi CFP yang tengah dipelajari.

\begin{tabular}{|c|c|c|c|c|}
\hline Parameter, Unit & $\begin{array}{l}\text { HTR- } \\
10[3]\end{array}$ & $\begin{array}{l}\text { HTR- } \\
\text { PM [5] }\end{array}$ & $\begin{array}{c}\text { PBMR } \\
{[6]}\end{array}$ & $\begin{array}{l}\text { Studi } \\
\text { ini }\end{array}$ \\
\hline Radius kernel, mm & 0,25 & 0,25 & 0,25 & 0,25 \\
\hline $\begin{array}{l}\text { Ketebalan lapisan } \\
\text { pertama PyC, mm }\end{array}$ & 0,090 & 0,095 & 0,095 & 0,09 \\
\hline $\begin{array}{l}\text { Densitas lapisan } \\
\text { pertama PyC, } \mathrm{g} / \mathrm{cm}^{3}\end{array}$ & 1,1 & 1,1 & 1,05 & 1,1 \\
\hline $\begin{array}{l}\text { Ketebalan lapisan } \\
\text { kedua PyC, mm }\end{array}$ & 0,04 & 0,04 & 0,04 & 0,04 \\
\hline $\begin{array}{l}\text { Densitas lapisan } \\
\text { kedua } \mathrm{PyC}, \mathrm{g} / \mathrm{cm}^{3}\end{array}$ & 1,9 & 1,9 & 1,9 & 1,9 \\
\hline $\begin{array}{l}\text { Ketebalan lapisan } \\
\text { ketiga } \mathrm{SiC}, \mathrm{mm}\end{array}$ & 0,035 & 0,035 & 0,035 & 0,035 \\
\hline $\begin{array}{l}\text { Densitas lapisan } \\
\text { ketiga } \mathrm{SiC}, \mathrm{g} / \mathrm{cm}^{3}\end{array}$ & 3,18 & 3,18 & 3,18 & 3,18 \\
\hline $\begin{array}{l}\text { Ketebalan lapisan } \\
\text { keempat PyC, mm }\end{array}$ & 0,04 & 0,04 & 0,04 & 0,04 \\
\hline $\begin{array}{l}\text { Densitas lapisan } \\
\text { keempat PyC, } \\
\mathrm{g} / \mathrm{cm}^{3}\end{array}$ & 1,9 & 1,9 & 1,9 & 1.9 \\
\hline Jenis elemen bakar & $\mathrm{UO}_{2}$ & $\mathrm{UO}_{2}$ & $\mathrm{UO}_{2}$ & $\mathrm{UO}_{2}$ \\
\hline Pengayaan uranium & $17 \%$ & $17 \%$ & $9.6 \%$ & $10 \%$ \\
\hline Fraksi CFP & $5 \%$ & $7 \%$ & $9 \%$ & $5-60 \%$ \\
\hline
\end{tabular}

\begin{tabular}{|c|c|c|c|c|c|}
\hline $\begin{array}{c}\text { Fraksi } \\
\text { CFP }\end{array}$ & $\begin{array}{c}\text { Jumlah } \\
\text { CFP } \\
\text { per } \\
\text { bola }\end{array}$ & $\begin{array}{c}\text { Volume } \\
\text { zona } \\
\text { elemen } \\
\text { bakar } \\
\left(\mathrm{cm}^{3}\right)\end{array}$ & $\begin{array}{c}\text { Volume } \\
\text { bola } \\
\text { elemen } \\
\text { bakar } \\
\left(\mathrm{cm}^{3}\right)\end{array}$ & $\begin{array}{c}\text { Volume } \\
\text { total } \\
\mathrm{CFP} \\
\left(\mathrm{cm}^{3}\right)\end{array}$ & $\begin{array}{c}\text { Tebal } \\
\text { buffer } \\
\text { (porous } \\
\text { carbon } \\
\text { buffer) } \\
(\mu \mathrm{m})\end{array}$ \\
\hline $5 \%$ & 8300 & 65,5 & 113,1 & 3,3 & 90 \\
\hline $10 \%$ & 16600 & 65,5 & 113,1 & 6,5 & 90 \\
\hline $15 \%$ & 24900 & 65,5 & 113,1 & 9,8 & 90 \\
\hline $20 \%$ & 33201 & 65,5 & 113,1 & 13,1 & 90 \\
\hline $25 \%$ & 41501 & 65,5 & 113,1 & 16,4 & 90 \\
\hline $30 \%$ & 49801 & 65,5 & 113,1 & 19,6 & 90 \\
\hline $35 \%$ & 58101 & 65,5 & 113,1 & 22,9 & 90 \\
\hline $40 \%$ & 66401 & 65,5 & 113,1 & 26,2 & 90 \\
\hline $45 \%$ & 74701 & 65,5 & 113,1 & 29,5 & 90 \\
\hline $50 \%$ & 83001 & 65,5 & 113,1 & 32,7 & 90 \\
\hline $55 \%$ & 81301 & 65,5 & 113,1 & 36,0 & 90 \\
\hline $60 \%$ & 99602 & 65,5 & 113,1 & 39,3 & 90 \\
\hline
\end{tabular}

\subsection{Spesifikasi Desain Teras Reaktor}

Spesifikasi desain teras reaktor pebble bed yang digunakan dalam penelitian ini terlihat pada Tabel 3. Desain reaktor ini memiliki daya 40 MWt dengan bentuk silinder yang memiliki radius teras aktif dan tinggi teras aktif berturutturut adalah $90 \mathrm{~cm}$ dan $180 \mathrm{~cm}$ dengan ruang kosong di atas bola-bola elemen bakar sebesar $42 \mathrm{~cm}$. Material reflektor yang digunakan adalah graphite dengan ketebalan $100 \mathrm{~cm}$. Dimensi ini merupakan dimensi pada rentang yang hampir sama dengan dimensi teras HTR-10 dan Reaktor Daya Eksperimen (RDE) [8].

Tabel 3. Spesifikasi Desain Reaktor.

\begin{tabular}{lc}
\hline \multicolumn{1}{c}{ Parameter, Unit } & Nilai \\
\hline Daya reaktor, MWt & 40 \\
Tipe elemen bakar CFP & TRISO \\
Radius teras aktif, cm & 90 \\
Tinggi teras aktif, cm & 180 \\
Tebal reflektor, cm & 100 \\
\hline
\end{tabular}

\section{METODOLOGI}

Pada penelitian ini, perhitungan dilakukan dengan menggunakan metode Monte Carlo untuk memecahkan persamaan transport neutron yang diimplementasikan pada kode MVP/MVP-BURN [10,11]. Pada kode ini, elemen-elemen bakar yang berbentuk bola, baik itu coated fuel particle ataupun bola elemen bakar, diperlakukan terdistribusi secara acak berdasarkan Statistical Geometry Model (SGM). Pada SGM, posisi bola elemen bakar ditentukan secara probabilistik di sepanjang jalur pergerakan suatu partikel. Jarak ke bola berikutnya diambil sampelnya dari distribusi tetangga terdekat (Nearest Neighbor Distribution, NND) dengan tiga jenis NND digunakan tergantung pada titik awal partikel, yaitu partikel yang dimulai dari permukaan bola, partikel yang dimulai dari matriks dan partikel yang dimulai dari campuran stokastik. Dengan metoda ini, bolabola bahan bakar akan tersusun secara acak, seperti keadaan teras reaktor yang sebenarnya [12-14]. Hal ini merupakan perbedaan mendasar dengan metoda kisi (lattice) yang pada umumnya digunakan pada kode MCNP yang menyusun bola-bola elemen bakar secara teratur dan rapi dengan beberapa tipe penyusunan seperti BCC (Body Centered Cubic), FCC (Face Centered Cubic) atau yang lainnya $[15,16]$. Pada kode MVP, diberlakukan konsep double-heterogeneity, yaitu sebaran coated fuel particle pada bola elemen bakar (heterogeneity pertama) dan sebaran bola elemen bakar pada teras reaktor (heterogeneity kedua). Data nuklir yang digunakan dalam penelitian ini adalah Japan Evaluated Nuclear Data Library (JENDL) [17]. 


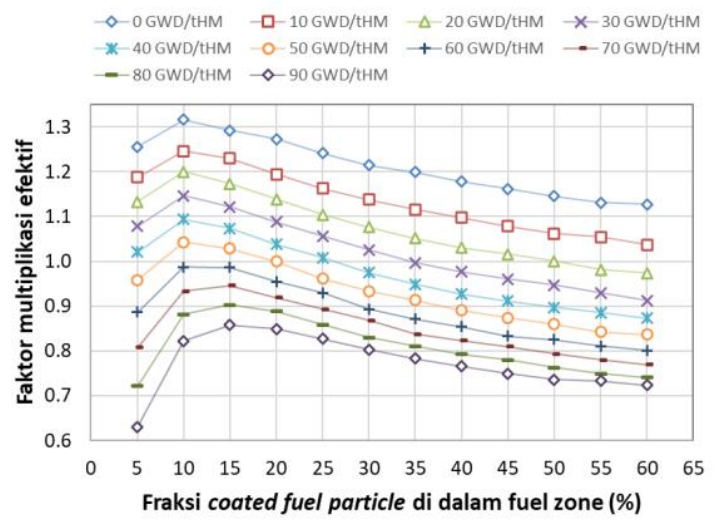

(a)

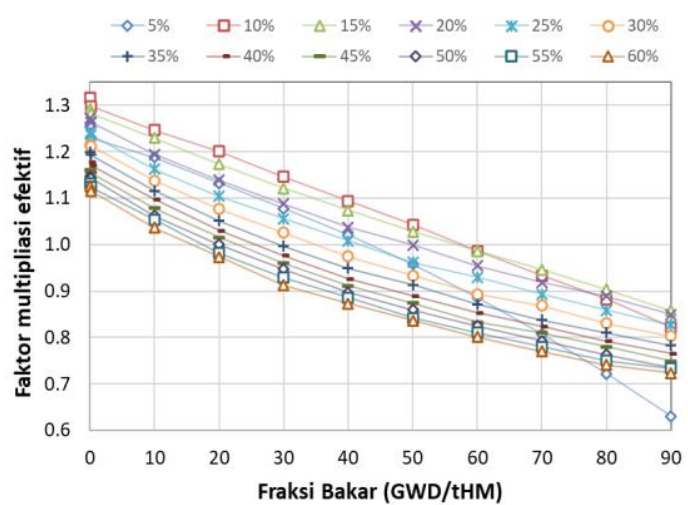

(b)

Gambar 2. (a) Pengaruh fraksi CFP (\%) terhadap faktor multiplikasi efektif dan level burnup. (b) Pengaruh fraksi CFP (\%) terhadap faktor multiplikasi efektif dan waktu burnup.

Pada penelitian ini, teras aktif yang berbentuk silinder diisi oleh elemen bakar berbentuk bola dan dikelilingi oleh reflektor. Digunakan total 100.000 neutron dengan 10 skip batches pada perhitungan dengan menggunakan MVP/MVP-BURN. Metodologi yang sama telah dikerjakan dan dibuktikan pada penelitan sebelumnya $[9,12,18]$.

Analisa dilakukan pada bola-bola elemen bakar dengan fraksi coated fuel particle yang berbeda, bervariasi antara $5-60 \%$, dengan selisih sebesar 5\%. CFP ini diisi dengan elemen bakar $\mathrm{UO}_{2}$ dengan pengayaan U235 sebesar 10\%. Bola-bola elemen bakar yang mengandung fraksi CFP berbeda, kemudian diletakan di dalam teras reaktor, dengan fraksi $61 \%$, selama selang waktu tertentu untuk mengetahui efek perbedaan fraksi CFP terhadap parameter-parameter penting neutronik yang juga dipengaruhi oleh besarnya burnup, periode burnup dan perubahan komposisi material yang ada di dalam reaktor.

\section{HASIL DAN PEMBAHASAN}

Gambar 2(a) menunjukkan besar nilai faktor multiplikasi efektif terhadap perubahan fraksi CFP pada berbagai level burnup. Faktor multiplikasi efektif yang merupakan perbandingan jumlah neutron pada satu generasi terhadap jumlah neutron pada generasi sebelumnya adalah parameter neutronik penting dalam pengoperasian reaktor nuklir, salah satunya karena dapat digunakan untuk menentukan masa operasi sebuah reaktor nuklir. Nilai standar deviasi dihitung dari akar variansi variabel random dan didapatkan sebesar $0.2 \%$, yang dikategorikan sebagai reasonable oleh MVP. Dari data yang didapatkan, diketahui bahwa faktor multiplikasi efektif akan berubah tergantung berapa besar fraksi CFP yang diberikan di dalam bola-bola elemen bakar. Saat nilai fraksi CFP yang digunakan adalah sebesar 5\%, nilai faktor multiplikasi efektif memiliki nilai yang relatif kecil karena ketersediaan material fisil di dalam teras reaktor yang terbatas. Nilai faktor multiplikasi efektif saat fraksi CFP yang digunakan adalah $10 \%$, memiliki nilai terbesar pada hampir setiap level burnup (0-60 GWD/T) dan merupakan nilai terbesar kedua atau ketiga pada level burnup yang lebih tinggi (70 GWD/T - 90 GWD/T).

Besar fraksi CFP 15\% hingga 60\% memiliki pola nilai yang cenderung menurun, dengan semakin besar fraksi CFP, maka semakin kecil nilai faktor multiplikasi efektif. Pola ini bersifat umum untuk setiap level burnup dari 0 sampai $90 \mathrm{GWD} / \mathrm{T}$. Nilai faktor multiplikasi efektif maksimum yang didapatkan ketika menggunakan fraksi CFP sebesar $10 \%$ di dalam bola elemen bakar, dapat pula dilihat menggunakan parameter waktu burnup seperti terlihat pada Gambar 2(b).

Dari hasil perhitungan didapatkan bahwa nilai faktor multiplikasi efektif terbesar setelah penggunaan $10 \%$ fraksi CFP adalah secara berturut-turut 15\%, 20\%, 25\% 5\%, 30\%, 35\%, 40\%, 45\%, 50\%, 55\% dan 60\%. Didapatkan juga bahwa fraksi CFP sebesar 5\% dapat mempertahankan kekritisan reaktor lebih sedikit dibandingkan dengan fraksi sebesar 10\%, 15\% dan 20\%. Dari data ini dapat 
dianalisa bahwa terdapat nilai optimum seberapa banyak fraksi CFP perlu ditambahkan di dalam bola elemen bakar. Nilai fraksi CFP yang terlalu kecil akan membuat reaktor beroperasi untuk masa operasi yang relatif sebentar, sedangkan fraksi CFP yang terlalu besarpun ternyata tidak efektif karena akan memberikan nilai faktor multiplikasi efektif yang tidak terlalu besar dengan masa operasi yang juga tidak panjang. Hal ini dapat dilihat dan dibuktikan dari perhitungan seperti terlihat pada Gambar 2(a) dan (b), untuk fraksi CFP sebesar $30 \%-60 \%$.

Pola seperti ini dapat dijelaskan dengan melihat spektrum energi neutron yang berada di dalam teras reaktor. Spektrum energi neutron ini akan dipengaruhi oleh fraksi CFP di dalam teras reaktor, karena berubahnya fraksi CFP akan ikut merubah perbandingan jumlah elemen bakar terhadap jumlah material moderator secara keseluruhan di dalam teras reaktor. Perbandingan jumlah elemen bakar terhadap moderator yang bernilai kecil, akan menyebabkan lebih banyak neutron cenderung memiliki energi yang rendah. Hal ini dikarenakan sedikitnya jumlah elemen bakar dan banyaknya jumlah moderator akan mengakibatkan neutron hasil reaksi fisi yang terlahir dengan energi tinggi, sekitar $2 \mathrm{MeV}$, akan banyak bertumbukan dengan atom-atom moderator sehingga termoderasi dan energinya secara signifikan akan berkurang. Pola ini dapat dilihat pada Gambar 3.

Pada daerah energi termal, penampang lintang reaksi fisi untuk U235 bernilai sangat besar. Dari perhitungan diketahui bahwa fraksi CFP sebesar $10 \%$ memiliki fluks neutron yang tertinggi. Fraksi CFP sebesar 15\%, 20\% serta $5 \%$ merupakan fraksi yang memiliki fluks relatif tinggi lainnya. Pola ini sejalan dengan fenomena yang terlihat pada Gambar 2(a) dan 2(b), dimana fraksi CFP sebesar 10\% memiliki nilai faktor multiplikasi efektif yang tertinggi, kemudian diikuti oleh fraksi CFP sebesar $15 \%$, $20 \%$ serta $5 \%$.

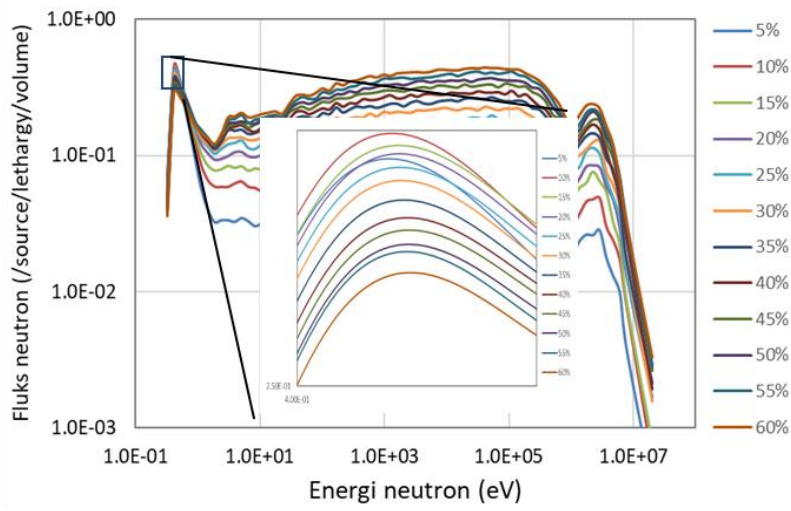

Gambar 3. Spektrum energi neutron akibat pengaruh fraksi $\mathrm{CFP}(\%)$

Dari Gambar 2 - 3, dapat dilihat bahwa penambahan fraksi CFP yang besar, di atas $30 \%$, tidak serta merta akan menaikkan nilai faktor multiplikasi efektif pada desain reaktor ini. Hal ini dikarenakan perbandingan elemen bakar terhadap moderator yang tinggi, akan menjadikan jumlah neutron yang memiliki spektrum energi rendah menjadi semakin sedikit.

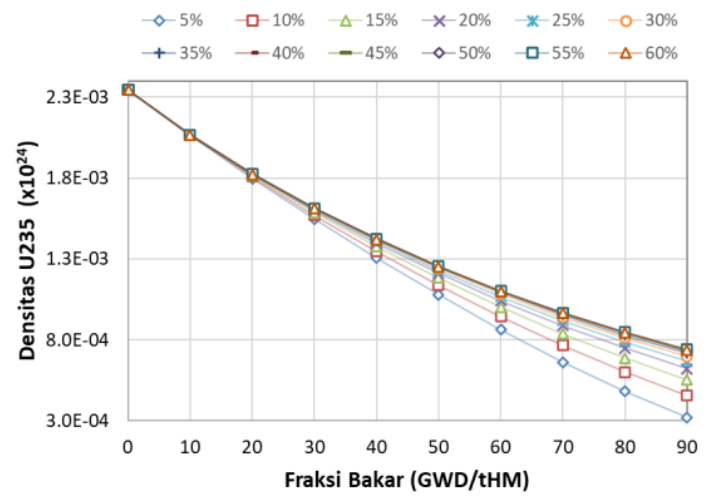

(a)

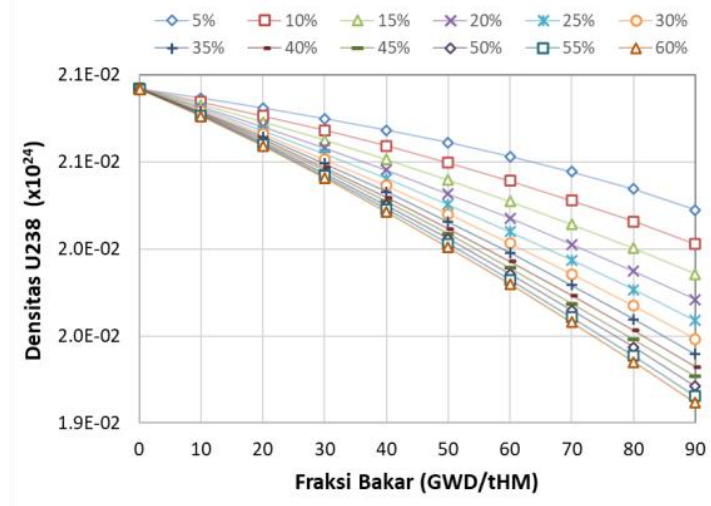

(b)

Gambar 4. (a) Densitas U235 akibat pengaruh fraksi CFP (\%). (b) Densitas U238 akibat pengaruh fraksi CFP (\%). 


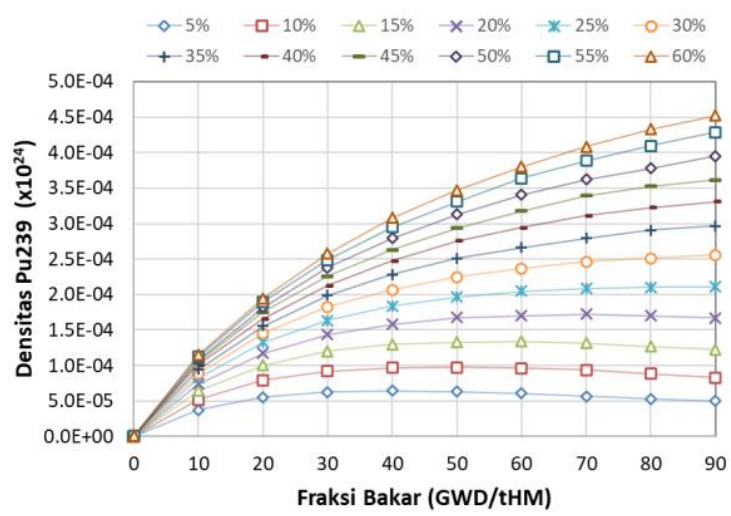

(a)

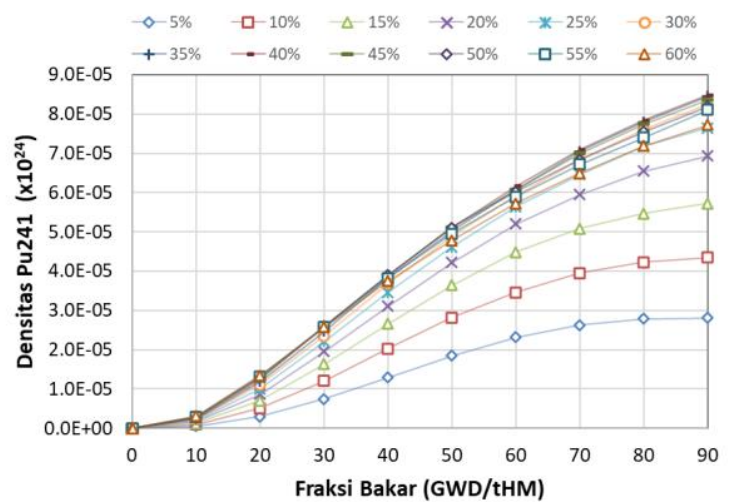

(b)
Mengingat bahwa penampang lintang reaksi fisi untuk U235 secara signifikan bernilai tinggi pada daerah spektrum neutron yang rendah, maka didapatkan nilai faktor multiplikasi efektif yang relatif lebih rendah untuk fraksi CFP yang tinggi. Untuk melihat lebih dalam tentang pengaruh fraksi CFP di dalam reaktor, kita bisa melihat data densitas material fertil dan fisil untuk U235, U238, Pu239 dan Pu241 seperti terlihat berturutturut pada Gambar 4 dan 5.

Jumlah U235 sepanjang waktu semakin menurun akibat penggunaannya pada reaksi fisi, dengan fraksi CFP yang lebih kecil akan memiliki tingkat penurunan yang lebih banyak dibandingkan dengan fraksi CFP yang lebih besar. Hal ini kembali dikaitkan dengan spektrum neutron yang lebih rendah untuk fraksi CFP yang lebih rendah, yang disebabkan oleh tingkat moderasi yang lebih tinggi akibat rendahnya perbandingan jumlah elemen bakar dan moderator.

Untuk densitas U238, spektrum energi intermediate menjadi penting karena penampang lintang penyerapan (absorpsi) pada daerah tersebut memiliki nilai resonansi yang sangat besar dibandingkan pada daerah rendah ataupun tinggi. Jika kita lihat kembali Gambar 3, kita mendapatkan data perhitungan bahwa fraksi CFP yang besar akan memiliki nilai energi yang besar dibandingkan dengan fraksi CFP yang kecil di rentang energi tinggi. Hal inilah yang menyebabkan perubahan densitas U238 untuk fraksi CFP yang besar lebih signifikan dibandingkan dengan perubahan densitas U238 untuk fraksi CFP yang kecil, seperti terlihat pada Gambar 4(b).

Pola perubahan densitas U238, akan mempengaruhi pola pembentukan Pu239 dan
Pu241 karena baik Pu239 maupun Pu241 dapat diperoleh dari U238. Pembentukan Pu239 dan Pu241 untuk fraksi CFP yang besar akan lebih signifikan dibandingkan perubahan densitas Pu239 dan Pu241 untuk fraksi CFP yang kecil seperti terlihat pada Gambar 5

Parameter lain yang ditinjau dari studi ini adalah besarnya pemanfaatan material fisil selama reaktor beroperasi. Parameter ini menjadi hal yang penting, karena CFP adalah konsep yang membuat elemen bakar menjadi lebih sulit untuk diolah ulang karena struktur TRISO (Tristructural Isotropic Particle) yang membungkus elemen bakar. Oleh karena itu, pemanfaatan material fisil yang berada di dalam CFP menjadi hal penting untuk dipertimbangkan. Gambar 6 menunjukkan data perhitungan tingkat utilisasi material fisil U235 terhadap level burnup. Nilai utilisasi U235 ini akan bergantung pada tingkat moderasi, spektrum energi neutron, serta banyaknya elemen bakar yang terpakai di dalam teras reaktor. Fraksi CFP sebesar 5\% memiliki tingkat utilisasi U235 tertinggi yaitu 86\%, sedangkan fraksi CFP sebesar 10\%, 15\% dan $20 \%$ berturut-turut memiliki nilai utilisasi U235 sebesar $81 \%, 76 \%$ dan $73 \%$ pada level burnup 90 GWD/T. Jika kita ingin mengoperasikan reaktor untuk masa operasi selama 1500 hari atau sekitar $50 \mathrm{GWD} / \mathrm{T}$, maka hanya fraksi CFP sebesar 10\% dan $15 \%$ yang dapat memenuhinya, seperti terlihat pada Gambar 2(b). Pada keadaan ini, utilisasi material fisil U235 terbesar adalah untuk fraksi CFP sebesar 10\%, yang bernilai $51 \%$, kemudian di bawah nilai tersebut terdapat fraksi CFP sebesar 15\% yang memiliki utilisasi U235 sebanyak $49 \%$. 


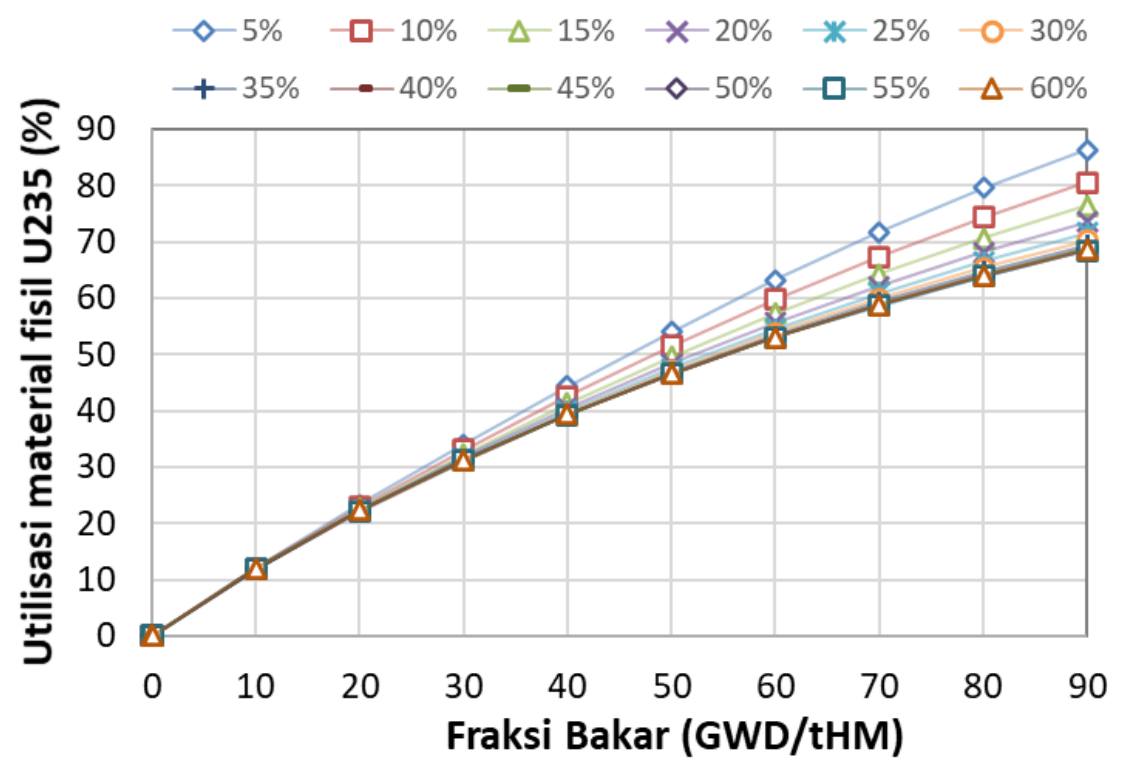

Gambar 6. Utilisasi material fisil U235 akibat pengaruh fraksi CFP (\%).

Dari hasil perhitungan dan analisa yang dilakukan pada parameter penting aspek neutronik yang ditinjau dalam penelitian ini, didapatkan fraksi CFP yang optimal untuk HTGR tipe pebble bed reactor berdaya 40 MWt adalah sebesar $10 \%$ atau sebanyak 16600 CFP dengan pengkayaan sebesar 10\%. Nilai ini berbeda dengan jumlah CFP yang digunakan oleh HTR-10 yang menggunakan pengkayaan sebesar $17 \%$ dan jumlah CFP sekitar 8300 [3], PBMR yang menggunakan pengkayaan sebesar 9,6\% dan jumlah CFP sebanyak 15000 [5], serta HTR-PM yang menggunakan nilai pengkayaan sebesar $17 \%$ dan jumlah CFP sebanyak 12000 [6]. Perbedaan ini terjadi karena setiap desain reaktor akan memiliki nilai optimal yang berbeda, tergantung pada target operasi serta pertimbangan parameter desain yang digunakan.

\section{KESIMPULAN}

Pada studi ini, pengaruh fraksi CFP pada parameter neutronik seperti faktor multiplikasi efektif, densitas material fisil dan fertil, utilisasi material fisil dan spektrum energi neutron telah dihitung dan dianalisa. Fraksi CFP akan mempengaruhi tingkat moderasi dan nilai spektrum energi neutron yang akan juga mempengaruhi nilai faktor multiplikasi efektif. Dari analisa yang dilakukan, didapatkan pula bahwa nilai fraksi coated fuel particle sebesar
$10 \%$ memberikan nilai optimal untuk faktor multiplikasi efektif dan memberikan nilai utilisasi U235 terbesar untuk masa operasi reaktor lebih dari 1500 hari, serta dapat dijadikan acuan untuk desain Pebble Bed Reactor berdaya $40 \mathrm{MWt}$ dengan elemen bakar uranium. Jika kita memasukan tinjauan pada aspek hidrolika panas dan keselamatan, perhitungan dan analisa tambahan perlu untuk dilakukan lebih lanjut untuk menyelidiki lebih lanjut nilai optimal pada desain reaktor ini.

\section{UCAPAN TERIMA KASIH}

Penulis mengucapkan terimakasih kepada Institut Teknologi Bandung atas dukungannya melalui Hibah Peningkatan Kapasitas.

\section{DAFTAR ACUAN}

[1] Paul A.Demkowicz, et.al. Coated particle fuel Historical perspectives and current progress. Journal of Nuclear Materials 515, 434-450, 2019.

[2] X.W.Zhou, et.al. Current status and future development of coated fuel particles for high temperature gas-cooled reactors, Progress in Nuclear Energy, Volume 53, Issue 2, March 2011, Pages 182-188, 2011.

[3] Youying Cheng, et.al. Uncertainty quantification of fuel pebble model and its effect on the uncertainty propagation of nuclear data in pebble bed HTR. Annals of Nuclear Energy 139, 107286, 2020. 
[4] Minoru Goto, et.al. Long-term high-temperature operation of the HTTR. Nuclear Engineering and Design, 251, 181-190, 2012.

[5] Adem Acır, et.al. Criticality and burnup analyses of a PBMR-400 full core using Monte Carlo calculation method. Annals of Nuclear Energy 38, 298-301, 2011.

[6] S. Knol, et.al. HTR-PM fuel pebble irradiation qualification in the high flux reactor in Petten. Nuclear Engineering and Design 329, 82-88, 2018.

[7] Suwoto, et.al. Analysis of Heavy Metal Loading Optimization Through Criticality Calculation on RDE. IOP Conf. Series: Journal of Physics: Conf. Series 1198, 022004, 2019.

[8] T. Setiadipura, et.al. Equilibrium Core Design of Reaktor Daya Eksperimental. IOP Conf. Series: Journal of Physics: Conf. Series 1198, 022076, 2019.

[9] D. Irwanto, et.al. Preliminary Study of $20 \mathrm{MWt}$ Experiment Power Reactor based Pebble Bed Gas Reactor. Journal of Physics: Conf. Series 877, 012058, 2017.

[10] Y. Nagaya, et. al. MVP/GMVP II, JAERI 1348, 388p, 2005.

[11] K. Okumura, et. al. MVP-BURN. Japan Atomic Energy Agency, 2005.

[12] Yasunobu Nagaya, et.al. Analysis of the HTR-10 Initial Core with a Monte Carlo Code MVP, PHYSOR
2004. Presented at The Physics of Fuel Cycles and Advanced Nuclear Systems: Global Developments, Chicago, Illinois, April 25-29, American Nuclear Society, Lagrange Park, IL, 2004.

[13] Hai Quan Ho, et.al. Investigation of uncertainty caused by random arrangement of coated fuel particles in HTTR criticality calculations. Annals of Nuclear Energy, 112, 42-47, 2018.

[14] Hai Quan Ho, et.al. Numerical investigation of the random arrangement effect of coated fuel particles on the criticality of HTTR fuel compact using MCNP6. Annals of Nuclear Energy, 103, 114-121, 2017.

[15] L Wahid, et.al. Criticality and Burnup Study on Different TRISO Modelling of HTR Pebble. IOP Conf. Series: Journal of Physics: Conf. Series 1198, 022078, 2019.

[16] Meng-Jen Wang,et.al. Criticality calculations of the HTR-10 pebble-bed reactor with SCALE6/CSAS6 and MCNP5. Annals of Nuclear Energy 64, 1-7, 2014.

[17] K.Shibata, et al. J. Nucl. Sci. Technol, Vol 39, No.11, p. 1125-1136, 2002.

[18] D. Irwanto, et.al. Burnup characteristics of a peu à peu fuel loading scheme in a 110MWt simplified pebble bed reactor, Journal of nuclear science and technology 48 (11), 1385-1395, 2011. 